\title{
Vis-NIR spectroscopy: from leaf dry mass production estimate to the prediction of macro- and micronutrients in soybean crops
}

\author{
Marlon Rodrigues $\odot *$ Marcos Rafael Nanni $\odot$, Everson Cezar, \\ Glaucio Leboso Alemparte Abrantes dos Santos, Amanda Silveira Reis $\odot$, \\ Karym Mayara de Oliveira, and Roney Berti de Oliveira $\odot$ \\ State University of Maringá, Department of Agronomy, Maringá, Paraná, Brazil
}

\begin{abstract}
Our work aimed to evaluate the use of visible-near-infrared (Vis-NIR) spectroscopy for predicting the production of leaf dry mass (LDM), as well as macro- and micronutrients contents of soybean leaves grown after application of limestone-mining coproducts. The treatments were arranged within a triple factorial scheme $(6 \times 2 \times 2+2)$ and placed into pots in a greenhouse. We evaluated the following factors: type of input (limestone-mining coproducts), input particle size (filler and powder), and soil class (Arenosol and Ferralsol). After inputs incubation, the soybean was sown. Then, 42 days after sowing, we collected the foliar spectra, as well as leaves, for further analysis of the contents of macro- and micronutrients in leaves and production of LDM. We managed to adjust models at the stage of prediction with $R^{2}{ }_{\mathrm{p}}>0.50$ and $\mathrm{RPD}_{\mathrm{p}}>1.50$ for the variables LDM, P, K, Mg, S, and Zn, with emphasis on the first four, which presented $R_{\mathrm{p}}^{2}$ above 0.65 . Therefore, we conclude that Vis-NIR spectroscopy has a potential for predicting LDM and the nutrients contents of soybean subjected to the application of limestonemining coproducts, with advantages such as speed, low cost, and no use of reagents that are toxic to the environment. (C) The Authors. Published by SPIE under a Creative Commons Attribution 4.0 Unported License. Distribution or reproduction of this work in whole or in part requires full attribution of the original publication, including its DOI. [DOI: 10.1117/1.JRS.14.044505]
\end{abstract}

Keywords: spectroscopy; reflectance; prediction; nondestructive testing; absorption; chemistry.

Paper 200509 received Jul. 5, 2020; accepted for publication Oct. 12, 2020; published online Oct. 21, 2020.

\section{Introduction}

Soybean cultivation is an important source of protein for humans and animals. Brazil is the second largest producer of soybeans and the largest exporter in the world. ${ }^{1}$ In 2019 , the country was responsible for producing 115 million tonnes. ${ }^{2}$ Considering the importance of soybean for the world's economy, collecting information throughout cultivation is indispensable when it comes to trade planning, as well as local and global supply.

During their development, soybean plants require high amounts of nutrients that are provided by fertilizers. Overall, fertilization is done with soluble fertilizers, which, despite their high agronomic efficiency in making nutrients available rapidly, have some disadvantages such as high $\operatorname{costs}^{3}$ and low residual effect. In addition, when used in high amounts, they may cause environmental problems, such as eutrophication of rivers and groundwater. ${ }^{4}$ Thus, searching for alternative inputs containing soluble minerals that release nutrients to the plant, such as rock powder, remineralizers, or mining coproducts, has become increasingly common. The drawback when it comes to using these sources is related to the quantification, in the soil and in the plant, of the nutrients released by the latter. This process of analysis is the same for all soluble fertilizers, and it results in additional costs, which makes such sources an unappealing option.

Currently, determining the leaf nutrients contents released by alternative inputs is done using routine analyses, which are destructive and they use reagents that are usually toxic. Furthermore, they are costly and time-consuming. ${ }^{5}$ These characteristics often make it impossible to correct the nutrition of plants of annual cycle, such as soybean. In this context, the application of

*Address all correspondence to Marlon Rodrigues, marlon.rodrig@hotmail.com 
hyperspectral sensing using visible-near-infrared (Vis-NIR) sensor could be helpful in determining the leaf nutrients contents in soybean. The Vis-NIR spectroscopy is commonly used as a remote, non-destructive method for rapid analysis of many attributes of fresh leaves. Vis is the region where photosynthetic pigments, such as carotenoids, chlorophylls, and xanthophyll, absorb strongly. However, the reflection in NIR is dominated by structural reflection of turgid plant cells of the mesophyll. ${ }^{6}$ The use of Vis-NIR spectroscopy can assist in the evaluation of applications of alternative inputs since it is a clean and non-destructive way of evaluating the structural and morphological characteristics of leaves, among other parts of plants. Furthermore, due to the ease of data acquisition and processing, it allows application in areas with precision agriculture, having seen the large number of samples demanded in this type of agriculture.

Several studies have demonstrated the potential of this tool for predicting attributes such as water contents in the crops, ${ }^{7}$ productivity ${ }^{8}$ pigment levels, ${ }^{9,10}$ vegetation index,${ }^{11}$ and leaf nutrients contents, ${ }^{12}$ such as $\mathrm{N},{ }^{5,13} \mathrm{P},{ }^{11,13} \mathrm{~K},{ }^{11,13,14} \mathrm{Ca},{ }^{13,15}$ and $\mathrm{Mg} .{ }^{13,15}$ However, studies on the use of this technique for the prediction of nutrients in soybean (especially micronutrients) are scarce. This is due to the complexity of nutritional functions and the number of plant chemical compounds, which makes the estimation of leaf nutrients by means of reflectance Vis-NIR a procedure with difficulties in autocorrelation and collinearity. ${ }^{9,16}$ The difficulty is even greater in the case of micronutrients, which although they have an essential function in the development of plants, they are present in minor quantities.

In case of nutritional deficiency, the production of leaf dry mass (LDM) can be impaired due to loss of structural, enzymatic, and photosynthetic compounds that are essential for forming a vigorous plant. That way, variability in the production can occur at any time due to nutritional factors. Therefore, it becomes fundamental to understand the plant's response to a certain factor and correlate that answer to the spectral response obtained from its leaves. Understanding the patterns of leaves spectral behavior allows creating models of plant productivity estimate. ${ }^{17}$

Based on the potential aforementioned, we aim to solve two basic issues of current soybean production: (I) reducing dependency on the use of soluble fertilizers (through the application of limestone-mining coproducts) and (II) estimating LDM and leaf nutrients contents. That being said, the aim of this study is evaluating the potential of Vis-NIR spectroscopy for predicting macro- and micronutrients contents, as well as in the production of LDM of soybean subjected to the application of limestone-mining coproducts.

\section{Materials and Methods}

\subsection{Chemical and Mineralogical Characterization of the Inputs}

The materials used in this study, which are here called inputs or coproducts, were collected from a depth of 0 to $15 \mathrm{~m}$ in a limestone-mining area in Tietê, São Paulo, Brazil. These inputs, which are located at different depths, were named ritmite (from Irati formation), bituminous shale (BS) (from Irati formation), and Corumbataí formation (CF). The contents of $\mathrm{CaO}, \mathrm{MgO}, \mathrm{K}_{2} \mathrm{O}$, and $\mathrm{S}$ of the inputs used in this study are shown in Table 1.

Table 1 Total contents of $\mathrm{CaO}, \mathrm{MgO}, \mathrm{K}_{2} \mathrm{O}$, and $\mathrm{S}$ found in the inputs used in the experiment.

\begin{tabular}{lcccc}
\hline \hline & $\mathrm{CaO}$ & $\mathrm{MgO}$ & $\mathrm{K}_{2} \mathrm{O}$ & $\mathrm{S}$ \\
\cline { 2 - 5 } Inputs & \multicolumn{5}{c}{$\%$} \\
\hline Ritmite & 14.4 & 13.0 & 0.6 & 1.3 \\
BS & 3.5 & 3.2 & 2.2 & 1.6 \\
$\mathrm{CF}$ & 0.7 & 2.4 & 3.1 & 0.1 \\
\hline \hline
\end{tabular}


Mineralogy of the inputs was determined through x-ray diffraction with Shimadzu XRD6000 equipment, in a fraction smaller than $0.074 \mathrm{~mm}$, using $\mathrm{CuK} \alpha$ radiation in staircase sweep, at an interval of $2 \theta$ of $5^{\circ}$ to $70^{\circ}$, with angular step of $0.02^{\circ}$ in Bragg configuration. ${ }^{18}$ Afterward, the results were interpreted by comparison with the reference standards contained in the powder diffraction file. ${ }^{19}$

\subsection{Chemical and Particle-Size Characterization of the Soils}

To carry out the experiment, we used soil samples from the surface layer $(0$ to $20 \mathrm{~cm})$ of a Ferralsol and an Arenosol. ${ }^{20}$ They were collected from a native forest area in Mandaguari and Paranavaí, PR, Brazil, respectively. After collection, the samples were ground, air-dried, and sieved with a $1-\mathrm{cm}$ sieve. For chemical and clay content characterization, the samples were dried in an oven with forced-air circulation at $50^{\circ} \mathrm{C}$ until we obtained the constant mass. Then, the samples were ground and sieved with a 2-mm sieve. Determination of $\mathrm{P}$ and $\mathrm{K}^{+}$(Mehlich-1), $\mathrm{Ca}^{2+}, \mathrm{Mg}^{2+}, \mathrm{SO}_{4}{ }^{2-}, \mathrm{pH}$ (water 2:1), and $\mathrm{C}$ organic followed the methodologies proposed by Teixeira et al., ${ }^{21}$ whereas $\mathrm{Si}$ (soluble) followed the methodology described by Korndörfer. ${ }^{22}$ The contents of $\mathrm{H}+\mathrm{Al}$ were evaluated by the $\mathrm{pH}$ exchange of the sample against the SMP buffer. ${ }^{23}$ After determining the elements, we calculated the sum of bases $\left(\mathrm{SB}=\mathrm{Ca}^{2+}+\mathrm{Mg}^{2+}+\mathrm{K}^{+}\right)$and the potential capacity of cations exchange $\left(\mathrm{CEC}=\mathrm{SB}+\mathrm{H}^{+}+\mathrm{Al}^{3+}\right)$, as described in Table 2.

\subsection{Delineation and Experimental Procedure}

The study was conducted in a greenhouse at the State University of Maringá. The treatments were arranged within triple factorial scheme $(6 \times 2 \times 2+2)$, randomly designed with five repetitions, and placed into pots $(n=130)$ in a greenhouse. The factors taken into account were type of input, input particle size, and soil class. The types of input used were coproduct 1 (50\% $\mathrm{CF}+50 \%$ ritmite), coproduct $2(100 \% \mathrm{CF})$, coproduct 3 (100\% ritmite), coproduct 4 (100\% BS), coproduct $5(30 \% \mathrm{CF}+15 \% \mathrm{BS}+55 \%$ ritmite), and coproduct $6(55 \% \mathrm{CF}+15 \% \mathrm{BS}+30 \%$ ritmite). The two additional controls consisted of treatments in which there was no input application, one for each soil class evaluated. The doses of coproducts 1, 3, and 5 were calculated in accordance with the Soil Chemistry and Fertility Commission of Rio Grande do Sul and Santa Catarina (SCFC-RS/SC) ${ }^{24}$ according to the contents of $\mathrm{CaO}$ of the inputs and the $\mathrm{Ca}^{2+}$ of both soil classes since they are mainly characterized as sources of such nutrient. As for coproducts 2 , 4 , and 6, the doses were calculated in accordance with SCFC-RS/SC ${ }^{24}$ based on the contents of $\mathrm{K}_{2} \mathrm{O}$ of these inputs and the $\mathrm{K}^{+}$of the two soil classes, for they are a material with potential to be used as sources of that nutrient for the soil. The input particle sizes evaluated were filler $(100 \%$ smaller than $0.30 \mathrm{~mm})$ and powder $(100 \%<2.00 \mathrm{~mm}, 70 \%<0.84 \mathrm{~mm}, 50 \%<0.30 \mathrm{~mm})$. That gives them a theoretical reactivity of $100 \%$ and $68 \%$, respectively. The soil classes used were Arenosol and Ferralsol.

The treatments with the applied amounts of $\mathrm{K}_{2} \mathrm{O}, \mathrm{CaO}, \mathrm{MgO}$, and $\mathrm{S}$ are described in Table 3 .

The coproducts doses were applied into pots containing $3.0 \mathrm{~kg}$ of dry soil (Ferralsol and Arenosol). Humidity control aimed at keeping the values close to the field capacity of both soil classes used. The pots were placed inside a greenhouse for incubation during 140 days.

Table 2 Clay content and chemical attributes of the topsoil layer $(0$ to $20 \mathrm{~cm})$ of the Ferralsol and the Arenosol used in the study.

\begin{tabular}{lccccccccccccc}
\hline \hline & $\mathrm{Clay}^{\mathrm{a}}$ & $\mathrm{C}$ & $\mathrm{pH}$ & $\mathrm{pH}$ & $\mathrm{H}+\mathrm{Al}$ & $\mathrm{Al}$ & $\mathrm{Ca}$ & $\mathrm{Mg}$ & $\mathrm{CEC}_{\mathrm{p}}{ }^{\mathrm{b}}$ & $\mathrm{K}^{\mathrm{c}}$ & $\mathrm{P}^{\mathrm{c}}$ & $\mathrm{SO}_{4}$ & $\mathrm{~V}$ \\
\cline { 2 - 11 } Soil & $\mathrm{g} \mathrm{kg}^{-1}$ & $\left(\mathrm{H}_{2} \mathrm{O}\right)$ & $\left(\mathrm{CaCl}_{2}\right)$ & & \multicolumn{2}{c}{$\mathrm{cmol}_{\mathrm{c}} \mathrm{dm}^{-3}$} & & & $\mathrm{mg} \mathrm{dm}^{-3}$ & & $\%$ \\
\hline Ferralsol & 770 & 12.4 & 5.2 & 4.4 & 3.42 & 0.30 & 3.18 & 1.99 & 9.04 & 175.5 & 7.3 & 5.57 & 62 \\
Arenosol & 70 & 7.2 & 5.1 & 4.2 & 1.88 & 0.20 & 0.77 & 0.28 & 3.01 & 31.2 & 2.6 & 2.08 & 38 \\
\hline \hline
\end{tabular}

aPipette method.

${ }^{\mathrm{b} P o t e n t i a l}$ CEC.

${ }^{\mathrm{c}}$ Mehlich-1. 
Table 3 Description of the treatments with the applied amounts of $\mathrm{K}_{2} \mathrm{O}, \mathrm{CaO}, \mathrm{MgO}$, and $\mathrm{S}$.

\begin{tabular}{|c|c|c|c|c|c|c|}
\hline \multirow[b]{2}{*}{ Inputs } & \multirow[b]{2}{*}{ Particle size } & \multirow[b]{2}{*}{ Soil classes } & $\mathrm{K}_{2} \mathrm{O}$ & $\mathrm{CaO}$ & $\mathrm{MgO}$ & S \\
\hline & & & \multicolumn{4}{|c|}{$\mathrm{kgha}^{-1}$} \\
\hline \multirow[t]{4}{*}{ Control } & Filler & Ferralsol & - & - & - & - \\
\hline & Powder & & & & & \\
\hline & Filler & Arenosol & - & - & - & - \\
\hline & Powder & & & & & \\
\hline \multirow[t]{4}{*}{ Coproduct $1^{\mathrm{a}}$} & Filler & Ferralsol & 66 & 459 & 442 & 56 \\
\hline & Powder & & & & & \\
\hline & Filler & Arenosol & 260 & 1809 & 1740 & 221 \\
\hline & Powder & & & & & \\
\hline \multirow[t]{4}{*}{ Coproduct $2^{b}$} & Filler & Ferralsol & 130 & 30 & 103 & 4 \\
\hline & Powder & & & & & \\
\hline & Filler & Arenosol & 300 & 69 & 237 & 10 \\
\hline & Powder & & & & & \\
\hline \multirow[t]{4}{*}{ Coproduct $3^{\mathrm{a}}$} & Filler & Ferralsol & 19 & 459 & 414 & 42 \\
\hline & Powder & & & & & \\
\hline & Filler & Arenosol & 74 & 1809 & 1630 & 164 \\
\hline & Powder & & & & & \\
\hline \multirow[t]{4}{*}{ Coproduct $4^{\mathrm{b}}$} & Filler & Ferralsol & 130 & 208 & 187 & 94 \\
\hline & Powder & & & & & \\
\hline & Filler & Arenosol & 300 & 479 & 432 & 217 \\
\hline & Powder & & & & & \\
\hline \multirow[t]{4}{*}{ Coproduct $5^{a}$} & Filler & Ferralsol & 83 & 459 & 442 & 53 \\
\hline & Powder & & & & & \\
\hline & Filler & Arenosol & 329 & 1809 & 1742 & 209 \\
\hline & Powder & & & & & \\
\hline \multirow[t]{4}{*}{ Coproduct $6^{\text {b }}$} & Filler & Ferralsol & 130 & 310 & 338 & 42 \\
\hline & Powder & & & & & \\
\hline & Filler & Arenosol & 300 & 780 & 780 & 96 \\
\hline & Powder & & & & & \\
\hline
\end{tabular}

aDose based on the contents of $\mathrm{CaO}$ of the coproducts and the soil to reach the critical content of $\mathrm{Ca}^{2+}>4 \mathrm{cmol}_{\mathrm{C}} \mathrm{dm}^{-3}$.

${ }^{b}$ Dose based on the contents of $\mathrm{K}_{2} \mathrm{O}$ of the coproducts and the soil to reach the critical content of $\mathrm{K}>90 \mathrm{mg} \mathrm{dm}^{-3}$.

After incubation, we did the soil sampling with an auger for determining the macronutrients $\mathrm{K}^{+}$and $\mathrm{P}$ (Mehlich-1). Afterward, fertilization recommendations were followed in order to increase the contents of $\mathrm{P}$ and $\mathrm{K}^{+}$of the soil to the critical content of soybean (Glycine max L.) in accordance with what is recommended by SCFC-RS/SC. ${ }^{24}$ For correcting $\mathrm{P}$ and $\mathrm{K}^{+}$, we 
used triple superphosphate and coproduct $2(\mathrm{CF})$, respectively, both applied during sowing. We also inoculated soybean with Bradyrhizobium spp. for nitrogen fixation.

Right after application of the inputs that are sources of $\mathrm{P}$ and $\mathrm{K}$, and after inoculation, we sowed 10 soybean seeds (NIDERA NA5909) per vase, and when the plant reached the V1 stage, we did the thinning, which left 4 plants per pot. A few moments before collecting the soybean leaves, we acquired the radiometric data (reflectance) from the adaxial part of the leaves $(n=130)$ with the aid of an ASD leaf clip (next item). Leaves were collected 42 days after sowing, at the V6 stage. After that, the leaves were dried in an oven with forced-air circulation at $60^{\circ} \mathrm{C}$, until constant mass. Then, we evaluated the production of LDM, as well as the contents of $\mathrm{N}, \mathrm{P}, \mathrm{K}, \mathrm{Ca}, \mathrm{Mg}, \mathrm{S}, \mathrm{Cu}, \mathrm{Fe}, \mathrm{Mn}$, and $\mathrm{Zn}$. For N, at first, the tissue samples were subjected to sulfuric digestion and, after that, the $\mathrm{N}$ was determined through distillation in a semi-micro Kjeldahl device and titration with sulphuric acid $\left(0.025 \mathrm{moll}^{-1}\right)$. As for $\mathrm{S}$, first came nitricperchloric digestion, followed by extract precipitation with $\mathrm{BaCl}_{2}$ and determination through a UV-Vis spectrophotometer in transmittance form, in accordance with Da Silva. ${ }^{25}$ The other nutrients were determined using an inductively coupled plasma atomic emission spectrometer.

\subsection{Radiometric Data (Reflectance) of the Soybean}

The radiometric scanning of the soybean leaves was done with an ASD FieldSpec 3 spectroradiometer operating at 350 to $2500 \mathrm{~nm}$, with spectral resolution of $3 \mathrm{~nm}$ at 350 to $1400 \mathrm{~nm}$ and $30 \mathrm{~nm}$ at 1400 to $2500 \mathrm{~nm}$ [short-wave infrared (SWIR)]. Using the leaf clip allowed for collecting the leaf reflectance spectra of living vegetation directly in the greenhouse (Fig. 1). For spectra data collection, initially the spectroradiometer was optimized to adjust the sensitivity of the instrument's detectors according to the specific illumination conditions at the time of measurement with 20 scans per white reference (Spectralon standard). Then, to achieve the relative reflectance measurements, the white reference was collected before scanning the leaves samples until a nice, clean, $100 \%$ reference line was obtained according to the specifications provided by the Reflection and Calibration Laboratory. ${ }^{26}$ For each plant individual, three leaves were measured in reflectance mode. The mean was then calculated according to recommendations of Nanni and Demattê. ${ }^{27}$
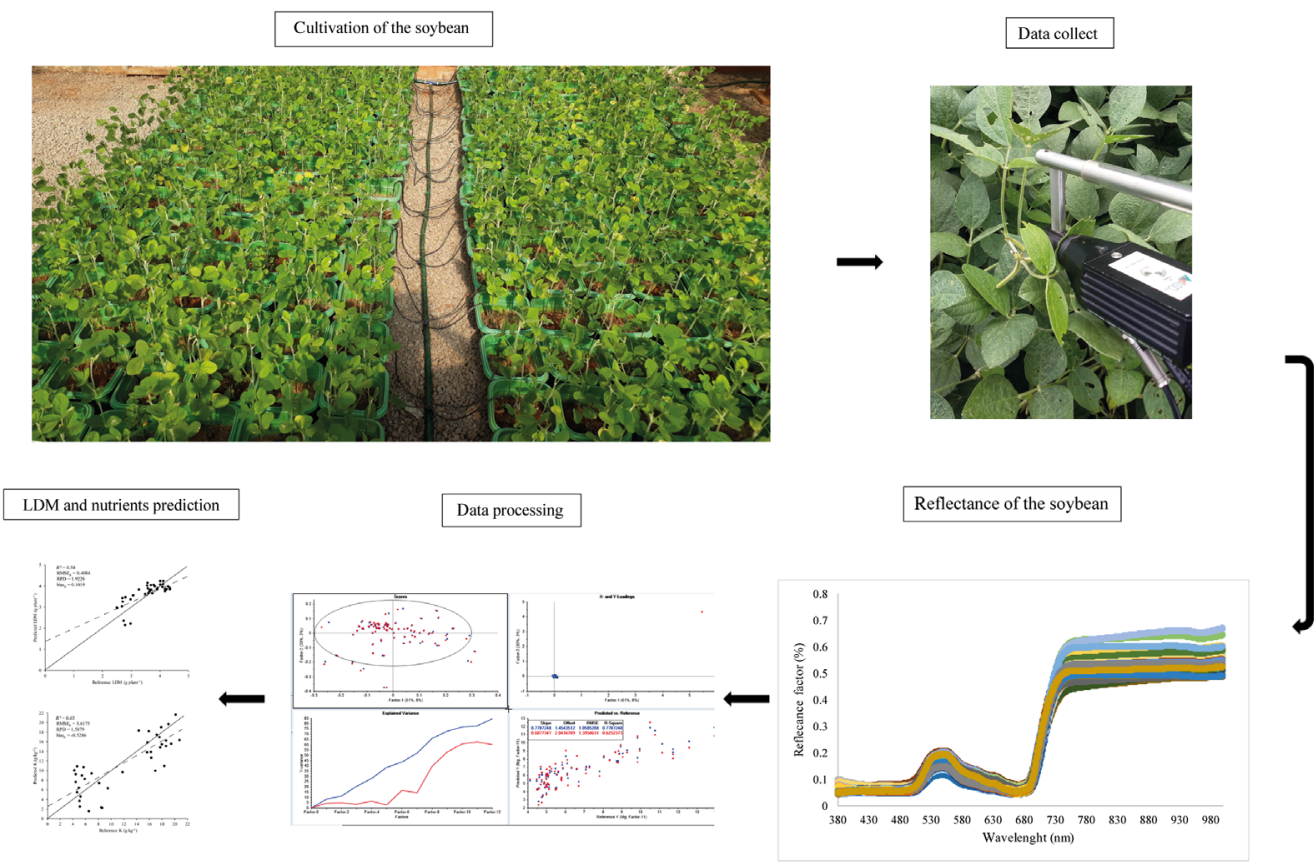

Fig. 1 Scheme of conducting the experiment and collecting spectral data on soybean. 


\subsection{Data Processing and Statistical Analysis}

The results of both LDM and contents of macro- and micronutrients of the leaves were initially subjected to descriptive statistical analysis with the Excel software-XLSTAT. ${ }^{28}$ We used The Unscrambler 10.4 software to smoothing the reflectance (soybean leaves) data through the multiplicative signal correction (MSC) method in order to reduce the additive scattering effect. ${ }^{29}$ The rationale behind MSC is to compensate for these additive effects. In addition, the preprocessing technique MSC was selected because it has been shown to improve the performance of spectroscopy models. The results were centered on the mean and subjected to partial least squares regression (PLSR) ${ }^{30}$ with the iterative algorithm NIPALS ${ }^{31}$ in order to estimate of LDM and macro- and micronutrients contents of soybean leaves.

To generate the prediction models from the reflectance spectrum (Vis-NIR), we first removed the wavelengths of marginal ( 350 to $379 \mathrm{~nm}$ ), considered to be of greater noise ${ }^{32}$ and only the wavelengths in the range between 380 and $1000 \mathrm{~nm}$ (Vis-NIR) were used since this range is often employed to probe the properties of living plant leaves. ${ }^{6}$ Subsequently, spectral scanning's of the 130 samples were divided into two groups. The first represented 91 samples used for generating the model (calibration), and the second represented 39 samples used for validating (prediction) the adjusted PLSR model. These samples were randomly selected from the data set, thus avoiding bias that could influence the model quality. The leave-one-out cross-validation (cv) method was used as a preliminary form of predicting the soybean attributes. ${ }^{33}$ In the prediction (p) process, parameters such as determination coefficient $\left(R^{2}\right)$, root-mean-square error (RMSE), ratio of performance to deviation (RPD), and bias were used to evaluate quality and accuracy of the model (Fig. 2). Rossel et al. ${ }^{34}$ and Saeys et al. ${ }^{35}$ state that the values of $R^{2}$ are classified as: $R^{2}<0.50$ (models with poor predictions only capable of distinguishing high and low values); $R^{2}$ between 0.50 and 0.65 (models with moderate predictions that may be used for evaluation and correlation); $R^{2}$ between 0.65 and 0.80 (good prediction models that enable quantitative predictions; $R^{2}$ between 0.80 and 0.90 (models of very good quantitative predictions); and, finally, $R^{2} \geq 0.90$ (excellent prediction models). Chang et al. ${ }^{36}$ and Dunn et al. ${ }^{37}$ have

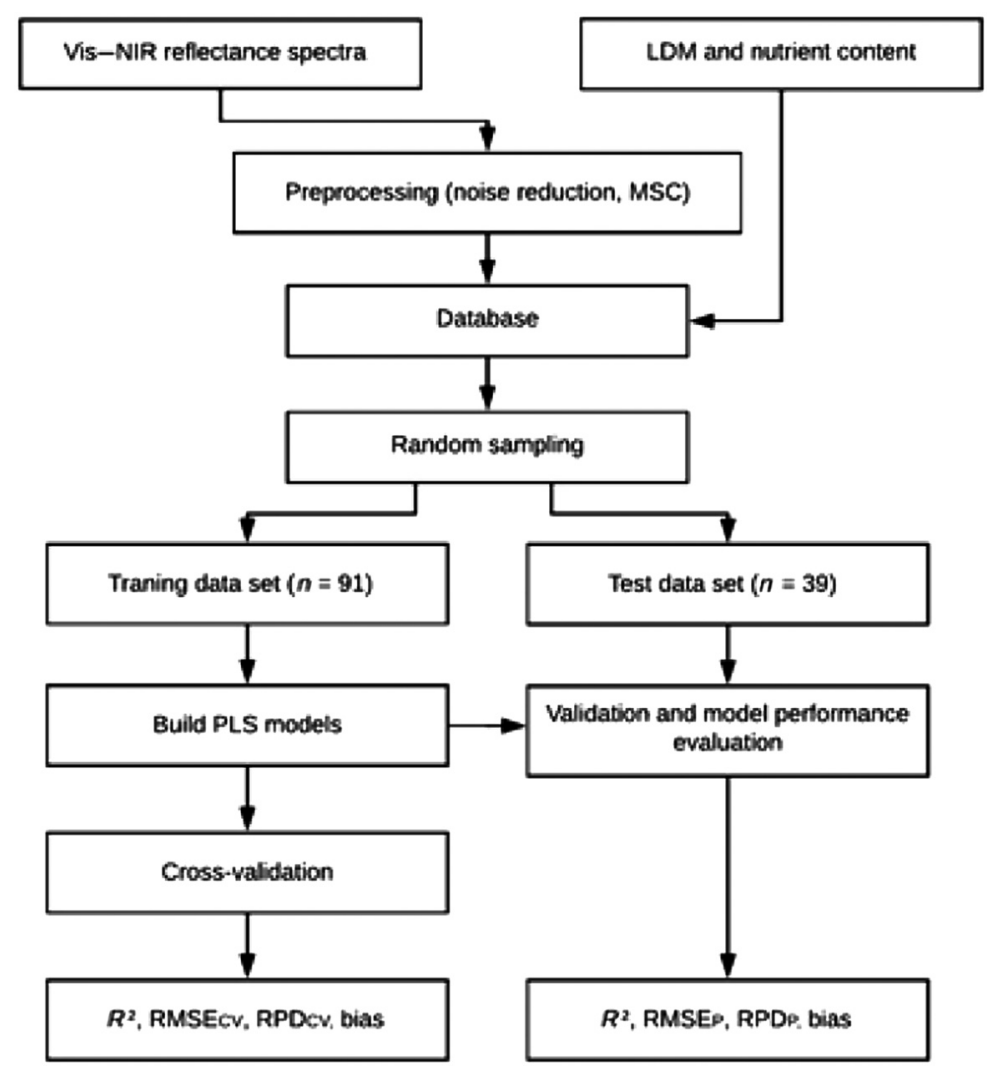

Fig. 2 Flowchart of the methodology used in the PLSR. 
suggested that models with RPD values lower than 1.5 should be considered insufficient for the majority applications, whereas models with RDP values between 1.5 and 2.0 are considered useful in relation to the accuracy of their predictions, and models with values greater than 2.0 should be considered excellent.

\section{Results}

\subsection{Mineralogical Characterization of the Coproducts}

Figure 3 shows the peaks of x-ray diffractometry of the coproducts used in the study, in compliance with Rodrigues et al. ${ }^{30}$ For ritmite [Fig. 3(a)], we verified peaks related to quartz, smectite, calcite, dolomite, and pyrite. As for CF [Fig. 3(b)], the peaks identified referred to smectite, illite, quartz, feldspar, and mica. Regarding BS [Fig. 3(c)], the peaks occurred due to quartz, albite, mica, and pyrite. These results, in most of the cases, corroborate the available literature on their mineralogy. ${ }^{38-40}$

\subsection{Descriptive Analysis of the LDM and Nutrients Contents of Soybean}

Table 4 shows the results of the descriptive analysis of LDM and the nutrients contents found in the soybean leaves after cultivation in soil incubated with mining coproducts. The coefficient of variation values (CV) ranged from $9.97 \%$ for $\mathrm{Ca}$ and $91.02 \%$ for $\mathrm{Mn}$.

\subsection{Estimation of LDM and Nutrients Contents of Soybean Using Vis-NIR Spectroscopy}

It can be noted in Fig. 4 that there was a separation between treatments evaluated when compared to their reflectance, which allows to infer about the possibility to use the spectral curves in the differentiation of treatments, as well as in the prediction of plants attributes (LDM and nutrients content). In addition, absorption valleys close to 497 and $690 \mathrm{~nm}$ can be noted due to chlorophyll $^{41}$ and in the range of 700 to $770 \mathrm{~nm}$, the reflectance sharply increases due to the
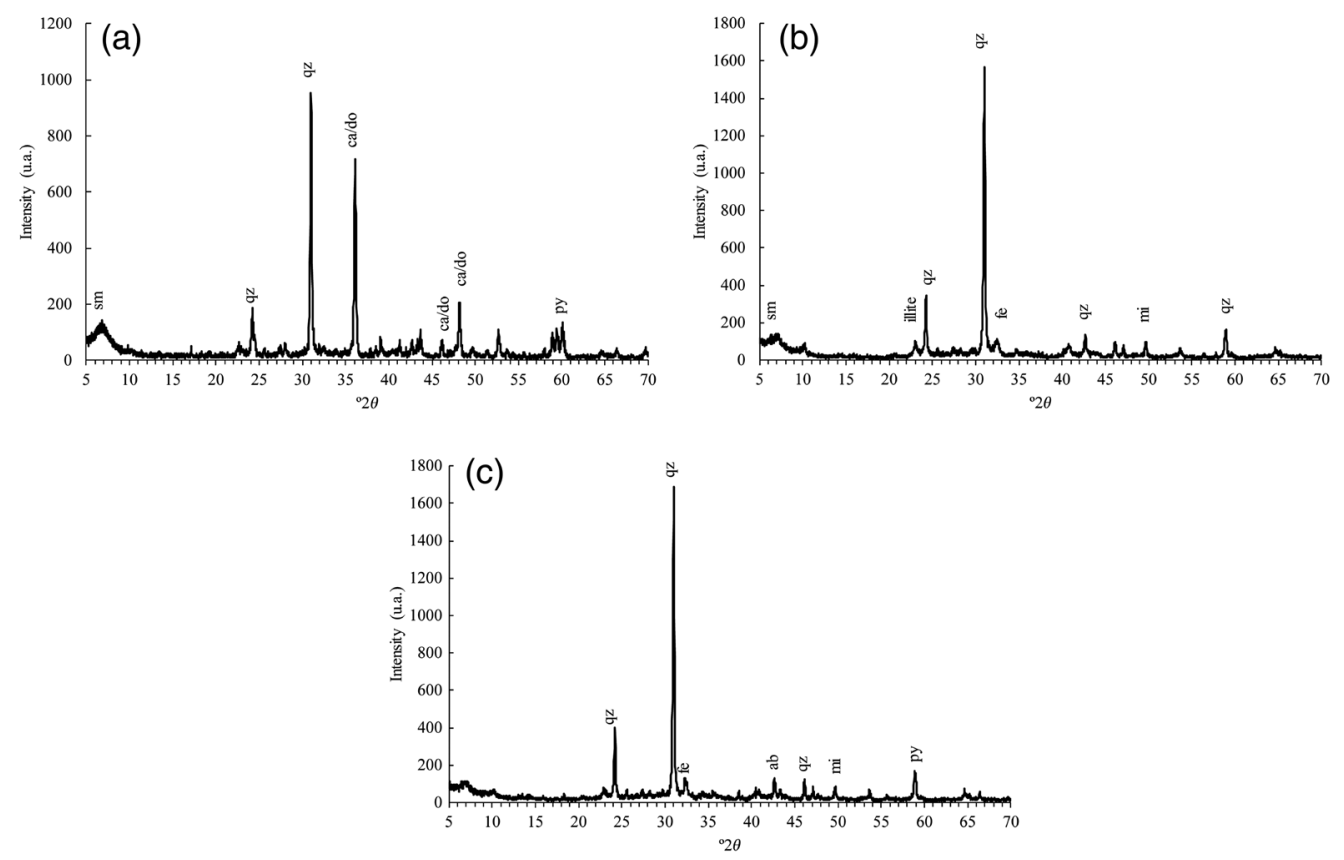

Fig. 3 X-ray diffractometry of the materials produced in limestone-mining: (a) ritmite, (b) CF, (c) BS. ca/do = calcite and dolomite, $\mathrm{sm}=$ smectite, $\mathrm{qz}=$ quartz, fe = feldspar, $\mathrm{py}=$ pyrite, $\mathrm{mi}=$ mica, and $a b=$ albite. $^{30}$ 
Table 4 Descriptive analysis of the LDM production and foliar nutrients contents of soybean subjected to the application of limestone-mining coproducts.

\begin{tabular}{lccccc}
\hline \hline Attributes & Minimum & Median & Mean & Maximum & CV (\%) \\
\hline $\mathrm{LDM}^{\mathrm{a}}\left(\mathrm{g} \mathrm{plant}^{-1}\right)$ & 1.90 & 3.57 & 3.52 & 4.43 & 13.84 \\
$\mathrm{~N}\left(\mathrm{~g} \mathrm{~kg}^{-1}\right)$ & 21.05 & 27.10 & 27.34 & 34.42 & 10.92 \\
$\mathrm{P}\left(\mathrm{g} \mathrm{kg}^{-1}\right)$ & 0.75 & 1.87 & 2.53 & 6.46 & 60.12 \\
$\mathrm{~K}\left(\mathrm{~g} \mathrm{~kg}^{-1}\right)$ & 12.45 & 11.81 & 21.22 & 48.64 \\
$\mathrm{Ca}\left(\mathrm{g} \mathrm{kg}^{-1}\right)$ & 3.82 & 10.03 & 10.07 & 12.48 & 9.97 \\
$\mathrm{Mg}\left(\mathrm{g} \mathrm{kg}^{-1}\right)$ & 7.23 & 5.73 & 6.92 & 13.93 & 37.53 \\
$\mathrm{~S}\left(\mathrm{~g} \mathrm{~kg}^{-1}\right)$ & 4.11 & 1.68 & 1.74 & 3.06 & 20.77 \\
$\mathrm{Cu}\left(\mathrm{mg} \mathrm{kg}^{-1}\right)$ & 1.06 & 5.94 & 6.61 & 47.55 & 68.78 \\
$\mathrm{Fe}\left(\mathrm{mg} \mathrm{kg}^{-1}\right)$ & 0.47 & 81.08 & 80.93 & 158.33 & 43.64 \\
$\mathrm{Mn}\left(\mathrm{mg} \mathrm{kg}^{-1}\right)$ & 1.78 & 115.51 & 163.17 & 729.43 & 91.02 \\
$\mathrm{Zn}\left(\mathrm{mg} \mathrm{kg}^{-1}\right)$ & 59.44 & 29.66 & 33.56 & 90.70 & 47.60 \\
\hline \hline
\end{tabular}

aeaf dry mass.
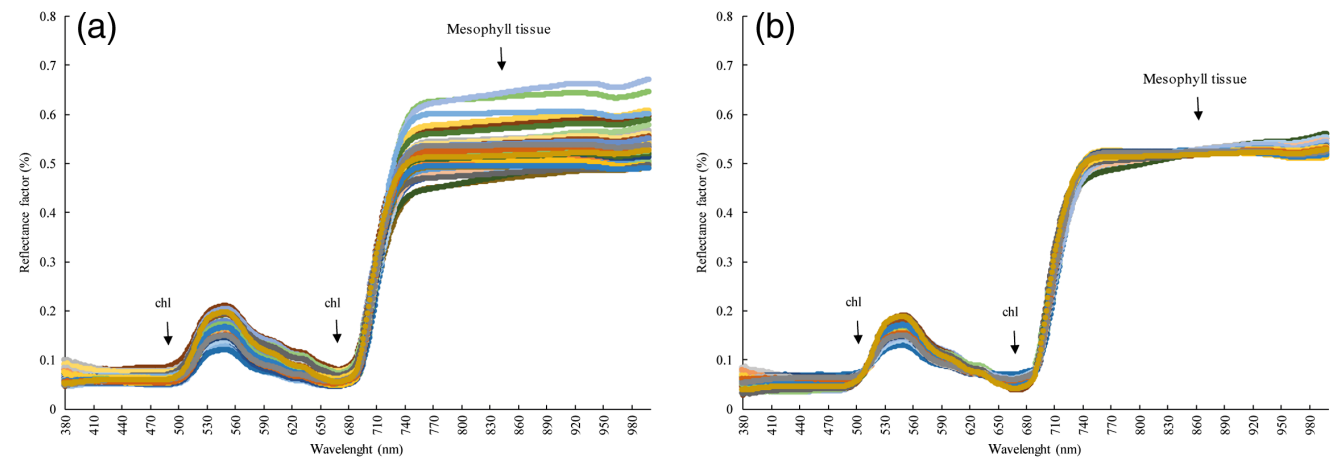

Fig. 4 Vis-NIR reflectance spectra raw of soybean (a) and after the preprocessing technique (MSC) (b) for all treatments. Chl = chlorophyll.

fact that there is a cavity with a large reflecting surface in the sponge tissue structure in the mesophyll. ${ }^{42}$

\subsubsection{Calibration (c) and cross-validation (cv)}

Table 5 shows the statistical parameters of the PLSR model for the phases of calibration and cross-validation of the LDM and the nutrients contents of soybean that were evaluated $(n=91)$. The values of the parameters evaluated $\left(R^{2}\right.$, RMSE, RPD, and bias) fluctuated depending on the variable studied.

We can see that, at the calibration phase (c) for nutrients $\mathrm{N}, \mathrm{Ca}$, and $\mathrm{Cu}$, the models generated were considered poor $\left(R_{\mathrm{c}}^{2}<0.32\right)$. For Fe and Mn variables, the models constructed were considered moderate $\left(R_{\mathrm{c}}^{2} 0.55\right.$ to 0.60$)$. As for nutrients $\mathrm{Mg}, \mathrm{S}$, and $\mathrm{Zn}$, the models were considered good $\left(R_{\mathrm{c}}^{2} 0.75\right.$ to 0.79$)$. Finally, for LDM and nutrients $\mathrm{P}$ and $\mathrm{K}$, the models were considered very good $\left(R^{2}{ }_{\mathrm{c}} 0.85\right)$. Regarding the $\mathrm{RMSE}_{\mathrm{c}}$, the values ranged from $0.1123 \mathrm{~g} \mathrm{plant}^{-1}$ for LDM to $61.3624 \mathrm{mg} \mathrm{kg}^{-1}$ for $\mathrm{Mn}$. As for bias, the values tended to be zero for all the variables.

At the cross-validation (cv) phase, we can see in Table 5 a decrease in the values of $R^{2} \mathrm{cv}$ related to the previous phase (c), as well as an increase in $\mathrm{RMSE}_{\mathrm{cv}}$. For $\mathrm{N}, \mathrm{Ca}, \mathrm{Cu}$, and $\mathrm{Mn}$ 
Table 5 Statistical parameters of the PLSR model for the LDM estimate and macro- and micronutrients contents of soybean $(n=91)$.

\begin{tabular}{|c|c|c|c|c|c|c|}
\hline Attributes & PLS factors & PLSR & $R^{2}$ & RMSE & RPD & BIAS \\
\hline \multirow[t]{2}{*}{ LDM (g plant ${ }^{-1}$ ) } & 10 & Calibration $^{\mathrm{a}}$ & 0.85 & 0.1123 & 4.33 & $5.3449^{-7}$ \\
\hline & & Cross validation ${ }^{\mathrm{b}}$ & 0.80 & 0.1418 & 3.44 & 0.0023 \\
\hline \multirow[t]{2}{*}{$N\left(g_{k g}^{-1}\right)$} & 2 & Calibration & 0.32 & 2.2537 & 1.32 & 0 \\
\hline & & Cross validation & 0.27 & 2.3649 & 1.26 & -0.0015 \\
\hline \multirow[t]{2}{*}{$P\left(g_{k g}^{-1}\right)$} & 11 & Calibration & 0.85 & 0.5925 & 2.56 & $1.1882^{-6}$ \\
\hline & & Cross validation & 0.84 & 0.5725 & 2.65 & 0.2106 \\
\hline \multirow[t]{2}{*}{$\mathrm{K}\left(\mathrm{g} \mathrm{kg}^{-1}\right)$} & 10 & Calibration & 0.85 & 2.2719 & 2.52 & $-7.3449^{-6}$ \\
\hline & & Cross validation & 0.80 & 2.5833 & 2.22 & 0.0221 \\
\hline \multirow[t]{2}{*}{$\mathrm{Ca}\left(\mathrm{g} \mathrm{kg}^{-1}\right)$} & 1 & Calibration & 0.13 & 0.9214 & 1.08 & 0.0233 \\
\hline & & Cross validation & 0.10 & 0.9721 & 1.03 & 0.1231 \\
\hline \multirow[t]{2}{*}{$M g\left(g ~ k g^{-1}\right)$} & 11 & Calibration & 0.79 & 1.0496 & 2.47 & $2.7785^{-6}$ \\
\hline & & Cross validation & 0.70 & 1.3983 & 1.85 & -0.0120 \\
\hline \multirow[t]{2}{*}{$S\left(g_{k g}^{-1}\right)$} & 12 & Calibration & 0.79 & 0.1743 & 2.07 & $-7.077^{-7}$ \\
\hline & & Cross validation & 0.56 & 0.2004 & 1.50 & 0.0091 \\
\hline \multirow[t]{2}{*}{$\mathrm{Cu}\left(\mathrm{mg} \mathrm{kg}^{-1}\right)$} & 1 & Calibration & 0.10 & 2.0123 & 2.26 & 0.0001 \\
\hline & & Cross validation & 0.08 & 2.1434 & 2.12 & 0.0012 \\
\hline \multirow[t]{2}{*}{$\mathrm{Fe}\left(\mathrm{mg} \mathrm{kg}^{-1}\right)$} & 7 & Calibration & 0.60 & 22.6511 & 1.56 & 0 \\
\hline & & Cross validation & 0.55 & 24.8644 & 1.42 & 0.9380 \\
\hline \multirow[t]{2}{*}{$\mathrm{Mn}\left(\mathrm{mg} \mathrm{kg}^{-1}\right)$} & 4 & Calibration & 0.55 & 61.3624 & 2.42 & 0 \\
\hline & & Cross validation & 0.45 & 72.8524 & 2.03 & -0.4377 \\
\hline \multirow[t]{2}{*}{$\mathrm{Zn}\left(\mathrm{mg} \mathrm{kg}^{-1}\right)$} & 9 & Calibration & 0.75 & 6.0321 & 2.64 & 0.0001 \\
\hline & & Cross validation & 0.60 & 7.6523 & 2.08 & -0.0391 \\
\hline
\end{tabular}

${ }^{\mathrm{a}}$ Calibration (c).

${ }^{\mathrm{b}}$ Cross-validation (cv).

variables, the models were considered poor $\left(R^{2}{ }_{\mathrm{cv}}<0.45\right)$. For $\mathrm{S}$, Fe, and $\mathrm{Zn}$ variables, the models with the $R_{\text {cv }}^{2}(0.55$ to 0.60$)$ were considered moderate. For $\mathrm{Mg}$, the model was considered $\operatorname{good}\left(R_{\mathrm{cv}}^{2} 0.70\right)$, and for LDM and the nutrients $\mathrm{P}$ and $\mathrm{K}$, the models generated were considered very good $\left(R_{\mathrm{cv}}^{2} 0.80\right.$ to 0.84$)$. With regard to the values of $\mathrm{RMSE}_{\mathrm{cv}}$, the values ranged from $0.1418 \mathrm{~g} \mathrm{plant}^{-1}$ for LDM to $74.8524 \mathrm{mg} \mathrm{kg}^{-1}$ for Mn. As for bias $\mathrm{cv}$, similarly to the calibration phase, the values found were close to zero.

As for the RPD values in the calibration phase, it is noted that the models presented results considered insufficient $(<1.32)$ for the variables $\mathrm{N}$ and $\mathrm{Ca}$ and useful for $\mathrm{Fe}(1.56)$. As for the variables $\mathrm{LDM}, \mathrm{P}, \mathrm{K}, \mathrm{Mg}, \mathrm{S}, \mathrm{Cu}, \mathrm{Mn}$, and $\mathrm{Zn}$, the models found, according to the RPD, were considered excellent $(>2.00)$. In the cross-validation phase, the models generated, considering their respective RPD, were considered insufficient for $\mathrm{N}, \mathrm{Ca}$, and $\mathrm{Fe}(<1.42)$, useful for $\mathrm{Mg}$ and $\mathrm{S}$ (1.85 and 1.50, respectively), and excellent for the other variables $(>2.03)$.

The models that were adjusted to predict the nutrient contents of the plant, as well as the best numbers of PLSR factors, were previously tested by cross-validation. Thus, the relationship between the predictor variable (reflectance) and the predicted one (LDM and nutrient contents) 
was better explained using the models containing 12 factors for $\mathrm{S} ; 11$ factors for $\mathrm{P}$ and $\mathrm{Mg}$; 10 factors for LDM and K; 9 factors for Zn; 7 factors for Fe; 4 factors for Mn; and 2 factor for $\mathrm{N}$. As for $\mathrm{Ca}$ and $\mathrm{Cu}$, the reliability of the model was limited since it presented only 1 factor.

\subsubsection{Prediction $(p)$}

To evaluate the capability of the PLSR models adjusted to predict LDM, as well as the nutrients contents in the leaf, these models were tested with a set of spectral data, different from those used for calibration and cross-validation. The scatter plot together with the results of the multivariate statistics is present in Fig. $5(n=39)$.

The $R_{\mathrm{p}}^{2}$ values found decreased in relation to the previous phases (c) and (cv). For variables $\mathrm{N}, \mathrm{Ca}, \mathrm{Cu}, \mathrm{Fe}$, and $\mathrm{Mn}$, the models generated according to $R_{\mathrm{p}}^{2}$ were considered poor $(<0.24)$. For variables $\mathrm{S}$ and $\mathrm{Zn}$, the models were considered moderate due to the $R^{2}$ found $(0.55$ and 0.58 , respectively). For LDM, P, and $\mathrm{Mg}$, the model was considered $\operatorname{good}\left(R_{\mathrm{p}}^{2} 0.65-0.70\right)$, and for $\mathrm{K}$, the model generated was considered very good $\left(R_{\mathrm{p}}^{2} 0.80\right)$. Regarding the RMSE $\mathrm{p}$, the values obtained ranged from $0.1584 \mathrm{~g} \mathrm{plant}^{-1}$ (LDM) to $80.5424 \mathrm{mg} \mathrm{kg}^{-1}$ (Mn). For bias, with the exception of nutrients $\mathrm{Fe}$ and $\mathrm{Mn}$, the values found were close to zero.
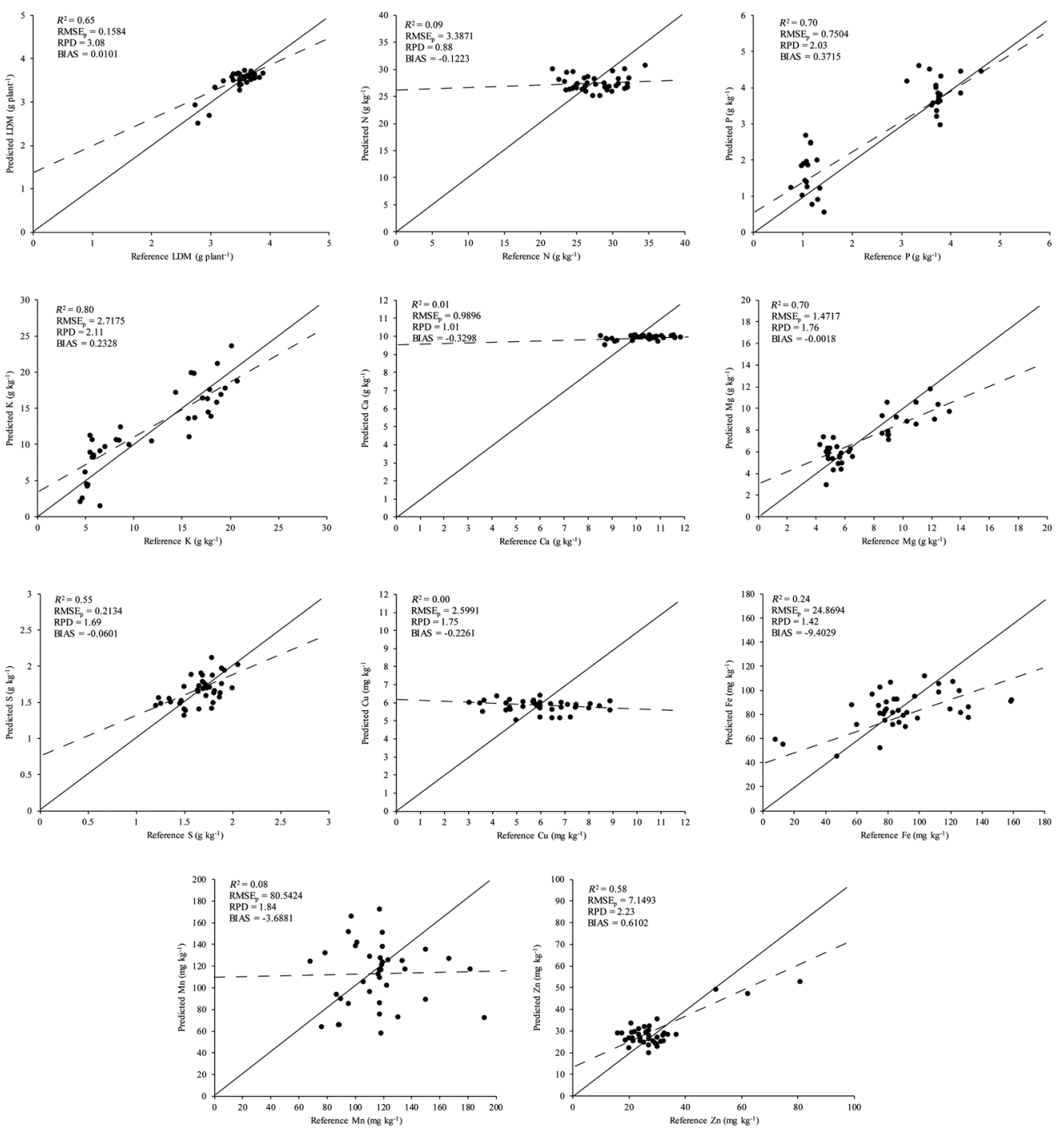

Fig. 5 Validation results for reference values versus predicted values for LDM and macro- and micronutrients contents of soybean $(n=39)$. Dotted and solid lines are for regression and 1:1, respectively. 
As for the RPD values, it is noted that the models presented results considered insufficient $(<1.42)$ for the variables $\mathrm{N}, \mathrm{Ca}$, and Fe. As for the variable LDM and the other nutrients evaluated, the models found, according to the RPD, varied between useful (1.5 to 2.0) and excellent $(>2.0)$.

The following are the correlation graphs between laboratory results (reference) and those obtained via Vis-NIR spectroscopy (predicted) (Fig. 5). As already mentioned, the variables LDM, K, Mg, Zn, S, and P were the ones with less dispersion and, consequently, better prediction capacity. On the other hand, the nutrients $\mathrm{N}, \mathrm{Ca}, \mathrm{Cu}, \mathrm{Fe}$, and $\mathrm{Mn}$ were the most dispersed and difficult to estimate.

\subsection{Interpretation of Regression Coefficients $(R C)$}

Figure 6 shows the regression coefficients of the PLSR model. We can observe regions of valleys and peaks where the RCs had a higher weight for the model construction. In general, the important wavelengths for the variables were close to 380 to $400 \mathrm{~nm}, 500$ to $530 \mathrm{~nm}, 600$ to $690 \mathrm{~nm}$, and 700 to $750 \mathrm{~nm}$.

For the LDM variable, we can see peaks and valleys, resulting from higher $\mathrm{RC}$, in the regions near 400, 500, and $530 \mathrm{~nm}$. For N, peaks and valleys are seen in regions near 600 and $750 \mathrm{~nm}$ [Fig. 6(b)]. The variables $\mathrm{P}$ and $\mathrm{K}$ presented higher $\mathrm{RC}$ in wavelengths close to 400,500 , and $700 \mathrm{~nm}$ [Figs. 6(c) and 6(d)]. The important wavelengths selected for Ca prediction are found in four regions, around 550 and $720 \mathrm{~nm}$, [Fig. 6(e)]. For Mg, higher RC is close to 400, 500, and $680 \mathrm{~nm}$ [Fig. 6(f)]. For S, the highest RC occurred at 400 and $700 \mathrm{~nm}$ [Fig. 6(g)].

Regarding $\mathrm{Cu}, \mathrm{Fe}$, and Mn [Figs. 6(h)-6(j)], despite several wavelengths with higher weights for the model construction, due to the low $R^{2}$ values found for these nutrients (Fig. 5), the RC found proved to be of little use. Finally, for Zn [Fig. 6(k)], higher RC was observed in regions near 400 and $620 \mathrm{~nm}$.

Table 6 describes the summary of the most responsive wavelengths according to the coefficient of the PLSR regression (Fig. 6) obtained for the estimation of the variables LDM production and nutrients contents of soybean.

\section{Discussion}

\subsection{Descriptive Analysis of the LDM and Nutrients Contents of Soybean}

The results obtained for the nutrients contents (plant) N, P, K, S, and Mn according to SCFC-RS$\mathrm{SC}^{24}$ were considered insufficient for the development of the crop. For $\mathrm{Cu}, \mathrm{Fe}$, and $\mathrm{Zn}$, the contents varied between insufficient and sufficient for the crop. Moreover, according to the Pimentel-Gomes ${ }^{43}$ classification, the coefficients of variation for the evaluated variables were classified as low for $\mathrm{Ca}$, medium for LDM and $\mathrm{N}$, high for $\mathrm{S}$, and very high for $\mathrm{P}, \mathrm{K}, \mathrm{Mg}, \mathrm{Cu}$, $\mathrm{Fe}, \mathrm{Mn}$, and $\mathrm{Zn}$. These results occurred because of the sources of nutrients used, such as mining coproducts. Due to the diversified mineralogy (Fig. 3), these coproducts provided varied input of elements, which contributed to the high range of minimum and maximum values of the nutrient contents. Furthermore, the use of inputs with different input particle size and solubility rates also favoured the heterogeneity in the coefficient of variation values found.

\subsection{Estimation of LDM and Nutrients Contents of Soybean Using Vis-NIR Spectroscopy}

Although the plant spectrum does not present characteristic inflections of the nutrients present in the plants, the peaks and dips caused by chlorophyll (Fig. 4) and the high reflectance of the NIR region typical of plants with the well-structured mesophyll ${ }^{44}$ are signs of satisfactory nutritional conditions. ${ }^{45,46}$ This allowed the construction of models, such as PLSR, which have the potential to make indirect predictions of nutrients. In addition, the production of LDM can also be directly related to the chlorophyll and the leaves' mesophyll, ${ }^{6}$ which allows its estimation, as discussed below. 
Rodrigues et al.: Vis-NIR spectroscopy: from leaf dry mass production estimate...
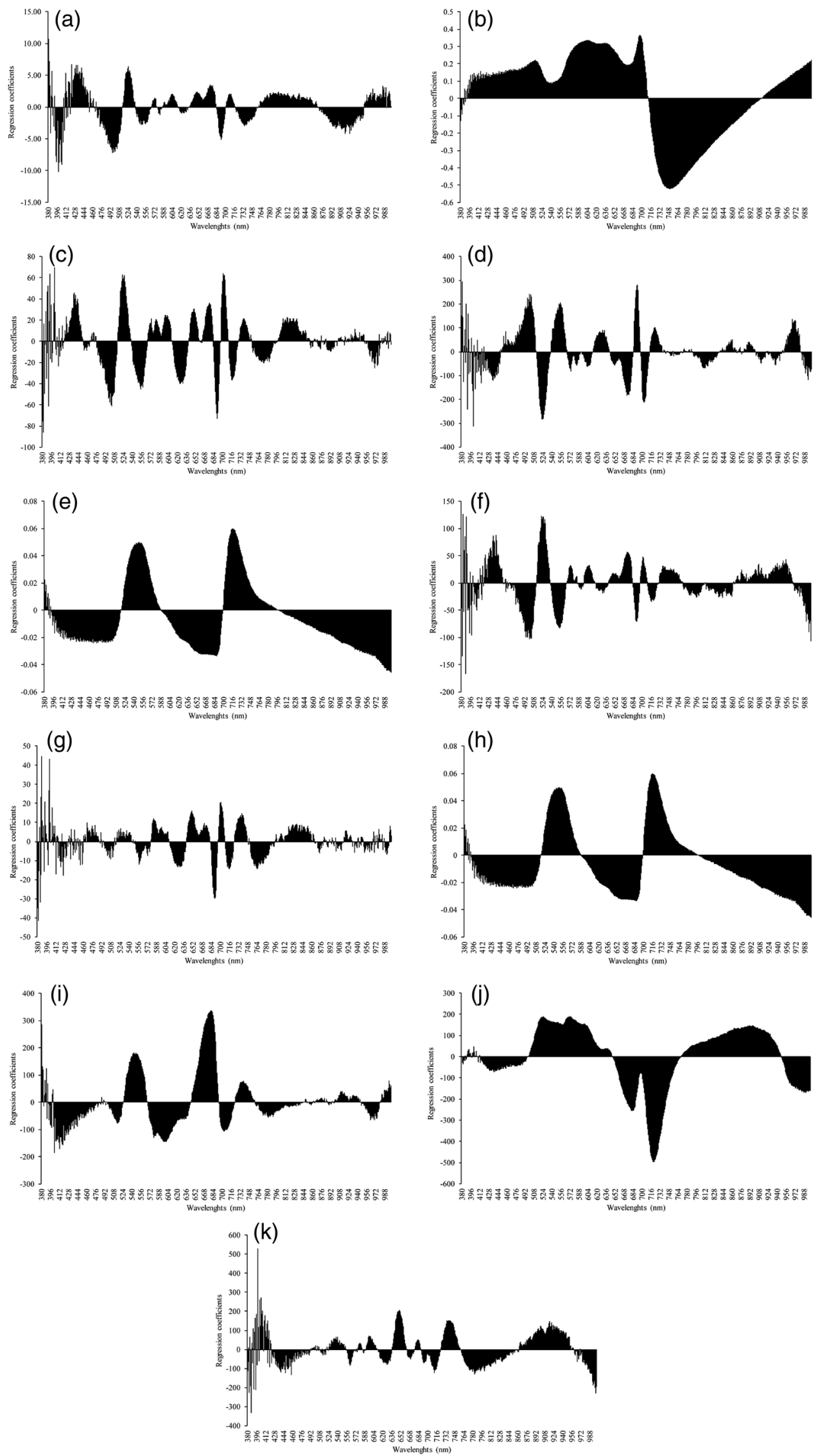

Fig. 6 Coefficient of the PLSR regression model for the variables (a) LDM, (b) N, (c) P, (d) K, (e) $\mathrm{Ca}$, (f) $\mathrm{Mg}$, (g) S, (h) Cu, (i) $\mathrm{Fe}$, (j) $\mathrm{Mn}$, and (k) $\mathrm{Zn}$ of soybean. 
Table 6 Most responsive wavelengths selected according to regression coefficients for variables LDM and nutrients contents of soybean.

\begin{tabular}{lccc}
\hline \hline $\begin{array}{l}\text { Plant } \\
\text { variable }\end{array}$ & $\begin{array}{c}\text { Most responsive } \\
\text { wavelengths }(\mathrm{nm})\end{array}$ & $\begin{array}{c}\text { Plant } \\
\text { variable }\end{array}$ & $\begin{array}{c}\text { Most responsive } \\
\text { wavelengths (nm) }\end{array}$ \\
\hline LDM & $400,500,530$ & $\mathrm{Ca}$ & 550,720 \\
$\mathrm{~N}$ & 600,750 & $\mathrm{Mg}$ & $400,500,680$ \\
$\mathrm{P}$ & 400,500 & $\mathrm{~S}$ & 400,700 \\
$\mathrm{~K}$ & 400,500 & $\mathrm{Zn}$ & 400,620 \\
\hline \hline
\end{tabular}

\subsubsection{Calibration (c) and cross-validation (cv)}

In the calibration phase of the models for $\mathrm{K}$ and $\mathrm{P}$ elements, which showed very good $R_{\mathrm{c}}^{2}(0.85)$, the results are corroborated by other studies using the Vis-NIR spectroscopy that also obtained high $R^{2}$ c values for these elements in barley ${ }^{47}$ and cucumber ${ }^{48}$ plants. Although $\mathrm{K}$ and $\mathrm{P}$ may not be directly detected when irradiated by Vis-NIR frequencies, organic compounds and other complex plant components containing these elements can be detected and evaluated when inspecting leaf spectra. ${ }^{49}$ Thus, the results obtained in this study demonstrate the potential of using Vis-NIR spectroscopy as a tool to help determine the contents of these nutrients in plants.

Regarding the cross-validation phase of the PLSR data, for variables $\mathrm{N}, \mathrm{Ca}, \mathrm{Cu}$, and $\mathrm{Mn}$, the results obtained in this study were below those achieved by Pandey et al. ${ }^{6}$ that when studying the use of Vis-NIR spectroscopy in the prediction of nutrients in maize and soybean leaves, they found $R^{2}$ cv for $\mathrm{N}, \mathrm{Ca}, \mathrm{Cu}$, and $\mathrm{Mn}$, respectively, of $0.88,0.75,0.80$, and 0.51 . For $\mathrm{N}$, this result was not expected since it is one of the elements associated with chlorophyll, ${ }^{11}$ which therefore interacts with electromagnetic radiation. ${ }^{5}$ For variables $\mathrm{Mg}, \mathrm{S}, \mathrm{Fe}$, and $\mathrm{Zn}(\mathrm{cv})$, the $R^{2}{ }_{\mathrm{cv}}$ were considered similar to those found by Pandey et al., ${ }^{6}$ who obtained values of $0.69,0.71,0.73$, and 0.64, respectively, for these nutrients. In relation to LDM, the results were similar to those of Silva-Perez et al., ${ }^{50}$ who found $R^{2}$ cv of 0.89 for this variable in wheat culture. For $\mathrm{P}$ and $\mathrm{K}$, the results of $R^{2}$ cv were slightly higher than the ones of Pimstein et al., ${ }^{51}$ who studied the use of VisNIR spectroscopy for predicting nutrients in maize culture and obtained $R^{2}$ of $\mathrm{P}=0.46$ and $R^{2}$ of $\mathrm{K}=0.77$. For $\mathrm{S}$, the results of $R^{2}$ cv were lower than those obtained by Pandey et al., ${ }^{6}$ who found $R^{2}$ cv of 0.71 for that nutrient. In relation to $\mathrm{Mg}$, these results were expected since this nutrient is part of the structure of the chlorophyll molecule, which presents strong interaction with electromagnetic radiation, what allows the creation of models with high $R^{2}{ }^{52}$ Other nutrients such as $\mathrm{K}, \mathrm{Ca}, \mathrm{Fe}, \mathrm{Mn}, \mathrm{Zn}$, and $\mathrm{Cu}$, all metallic elements that exist mainly as ions in living plant tissues, despite not presenting active spectral absorption characteristics in the Vis-NIR region, have the ability to bind electrostatically or act as binders for larger compounds containing carbon, what allowed relatively good PLSR models for some of them. ${ }^{6}$

The $\mathrm{RMSE}_{\mathrm{c}},{ }_{\mathrm{cv}}$ values ranged according to the analyzed variable (Table 5). For the nutrients $\mathrm{N}, \mathrm{K}, \mathrm{Ca}, \mathrm{S}, \mathrm{Cu}, \mathrm{Fe}, \mathrm{Mn}$, and $\mathrm{Zn}$, the $\mathrm{RMSE}_{\mathrm{cv}}$ values found in this study were lower than those of Pandey et al., ${ }^{6}$ who obtained $\mathrm{RMSE}_{\mathrm{cv}}$ values of $\mathrm{N}=4.70 \mathrm{~g} \mathrm{~kg}^{-1}, \mathrm{~K}=5.30 \mathrm{~g} \mathrm{~kg}^{-1}, \mathrm{Ca}=$ $3.50 \mathrm{~g} \mathrm{~kg}^{-1}, \mathrm{~S}=0.68 \mathrm{~g} \mathrm{~kg}^{-1}, \mathrm{Cu}=160 \mathrm{mg} \mathrm{kg}^{-1}, \mathrm{Fe}=111 \mathrm{mg} \mathrm{kg}^{-1}, \mathrm{Mn}=30.1 \mathrm{mg} \mathrm{kg}^{-1}$, and $\mathrm{Zn}=70.2 \mathrm{mg} \mathrm{kg}^{-1}$.

Another important parameter used to evaluate the calibration models is bias. For that, the values were insignificant, indicating that there was a random point distribution around the regression line, resulting in the absence of bias. ${ }^{33}$ As an example, for the variable $\mathrm{P}$, the bias $\mathrm{cv}_{\mathrm{cv}}$ of 0.2106 in the cross-validation phase indicates that the measurements for this variable are slightly lower than the reference values. ${ }^{53}$

\subsubsection{Prediction $(p)$}

In general, in the prediction phase (Fig. 5), the $R_{\mathrm{p}}^{2}$ values for the evaluated variables were lower than those found in the previous phases (calibration and cross-validation), demonstrating the 
limitation of the models to capture all data variability. ${ }^{33}$ However, the value of the bias ${ }_{p}$, with the exception of $\mathrm{Fe}$ and $\mathrm{Mn}$ elements, was low. That shows that there was no bias adjustment in the validation of the prediction models. The attributes that presented the best correlations between the laboratory routine analysis and the PLSR technique were, respectively, $\mathrm{K}, \mathrm{Mg}, \mathrm{P}$, and LDM since the $R_{\mathrm{p}}^{2}$ values found were between 0.65 and 0.80 and $R P D_{\mathrm{p}}$ above 2.03 , characterizing a modelling with good $\left(R_{\mathrm{p}}^{2}\right)$ and excellent $\left(\mathrm{RPD}_{\mathrm{p}}\right)$ adjustment. For the nutrients, the results were similar to those of Pandey et al., ${ }^{6}$ who found for $\mathrm{K}, \mathrm{Mg}$, and $\mathrm{P}, R_{\mathrm{p}}^{2}$ between 0.69 and 0.83 , and, in relation to $\mathrm{RPD}_{\mathrm{p}}$, values above 1.79. As for nutrients $\mathrm{N}, \mathrm{Ca}, \mathrm{S}, \mathrm{Cu}, \mathrm{Fe}, \mathrm{Mn}$, and $\mathrm{Zn}$, the same author found higher $R_{\mathrm{p}}^{2}$ and $\mathrm{RPD}_{\mathrm{p}}$ values similar to those found in this study. As for $\mathrm{S}$, the results in this study were similar to those found by Cozzolino and Moron ${ }^{54}$ who obtained $R^{2}{ }_{\mathrm{p}}$ of 0.65 working with leguminous crops.

Studies on $\mathrm{P}$ and $\mathrm{K}$ in other crops showed similar $R_{\mathrm{p}}^{2}$ when using the Vis-NIR range ${ }^{32}$ and lower when using visible, near-infrared, and short-wave infrared (Vis-NIR-SWIR) ${ }^{11}$ than the ones found in this study. Some elements (e.g., P) have no absorption in the NIR region, but they can be indirectly detected through their binding with organic complexes, chelates, and pigments, such as chlorophyll. ${ }^{54}$ Also, it has been found that potassium is associated with organic acids, especially malate. ${ }^{55}$ This makes its identification possible mainly in the wavelengths of the NIR, which have characteristics of electromagnetic radiation absorption associated with organic acids. ${ }^{56}$

For the LDM variable, the results of $R^{2}$ pere similar to those found of Garriga et al. ${ }^{57}$ who found $R_{\mathrm{p}}^{2}$ of 0.67 for forage production estimate and slightly lower than those of Tzanakakis et al., ${ }^{58}$ who found $R^{2}$ of 0.89 for the prediction of biomass production from forest species. According to Pimstein et al., ${ }^{51}$ the nutrients present inside plant tissues directly affect the development of biomass and, consequently, affect reflectance, which may have caused good prediction models for the LDM variable.

Regarding the variables $\mathrm{N}, \mathrm{Ca}, \mathrm{Cu}, \mathrm{Fe}$, and $\mathrm{Mn}$, the $R_{\mathrm{p}}^{2}$ found $(<0.50)$ indicated the existence of models with imprecise adjustments, thus harming the good prediction of plant nutrients. For $\mathrm{N}$, the results of $R_{\mathrm{p}}^{2}$ obtained in this study were lower than the ones of Tzanakakis et al. ${ }^{58}$ studying several crops and Zhang and $\mathrm{Li}^{48}$ in an experiment with cucumber.

A factor that may have compromised the good prediction of certain nutrients was the type of input used, in this case, mining coproducts. These materials are multi-elementary sources that provide different nutrients to plants in different quantities (Table 4), what makes it difficult to isolate the effect of a certain nutrient. Thus, the plants showed deficiencies for some nutrients such as N, P, K, S, and Mn, which may have presented a condition of "hidden hunger" that interferes with the spectral curve,${ }^{59}$ making it difficult to build the prediction model. Furthermore, the interaction between ions also influences the nutritional condition of the plant ${ }^{60}$ and consequently its spectral response.

In relation to micronutrients, several studies have shown that calibrations generally perform less well than those for macronutrients, ${ }^{61,62}$ as it was the case in this study. According Liao et al. ${ }^{62}$ and Menesatti et al., ${ }^{13}$ the NIR and Vis-NIR prediction of micronutrients may fail mainly because of their low concentrations in the leaves. However, for the micronutrient $\mathrm{Zn}$, according to Rossel et al. ${ }^{34}$ based on $R_{\mathrm{p}}^{2}$, the model shows moderate prediction that may be used for evaluation and correlation. Although $\mathrm{Zn}$ is a metallic ion, which does not produce inflections or absorption characteristics in the Vis-NIR region, it can bind electrostatically or as ligands to larger carbon-containing compounds, which enable the quantification by Vis-NIR spectroscopy. ${ }^{6}$

In relation to the $\mathrm{RMSE}_{\mathrm{p}}$, the variables that presented the smallest proportional values to the units of the evaluated variables were $\mathrm{S}, \mathrm{Ca}, \mathrm{LDM}$, and N. For these variables, the RMSE was below $12.5 \%$ in relation to the average of these variables. As for S and LDM, these results corroborate the highest $R^{2}$ found for these variables $(>0.50)$. Other studies report similar $\mathrm{RMSE}_{\mathrm{p}}$ values for $\mathrm{N}, \mathrm{P}$, and $\mathrm{K}$ in maize ${ }^{11}$ and lower for $\mathrm{N}, \mathrm{P}, \mathrm{K}, \mathrm{Ca}, \mathrm{Mg}, \mathrm{Fe}, \mathrm{Mn}$, and $\mathrm{Zn}$ in citrus $^{13}$ than those obtained in this study. 


\subsection{Interpretation of Regression Coefficients (RC)}

As for the RCs (Fig. 6), their interpretation is necessary to avoid possible accidental correlations. ${ }^{63}$ Thus, one can better understand how each variable (wavelength) contributes to the significant variation of the LDM estimate model and soybean nutrient contents. For the LDM variable, high RC close to $500 \mathrm{~nm}$ may be related to chlorophyll ${ }^{41}$ since studies have shown that wavelengths close to this region correlate with chlorophyll and plant nutrient concentration, ${ }^{64}$ which allows greater production of LDM.

Thus, the concentration of chlorophyll and nutrient contents are important for leaf mesophyll development, which may have caused high $\mathrm{RC}$ near $750 \mathrm{~nm}$. As for the $\mathrm{N}$ contents, the RC obtained in this study is supported by other studies that aimed at estimating nitrogen by the Vis-NIR spectroscopy in other crops, such as pepper ${ }^{65}$ and sugarcane. ${ }^{32}$ Concerning the variables $\mathrm{P}$ and $\mathrm{K}$, the results of the $\mathrm{RC}$ found in this study are corroborated by the work of Zhang et al., ${ }^{49}$ who studied the use of image Vis-NIR spectroscopy to predict $\mathrm{P}$ and $\mathrm{K}$ in rapeseed crop. Oliveira and Santana, ${ }^{6}$ when evaluating the use of Vis-NIR spectroscopy for the prediction of nutrients in Eucalyptus, also found high RC values in the region of 400 to $900 \mathrm{~nm}$ for P and N, as in this work. Both nutrients are closely related to photosynthetic traits in plants, ${ }^{67}$ which is directly related to high RC in the Vis-NIR reflectance. Pinstein et al. ${ }^{51}$ found, in the most part of the spectrum Vis-NIR, a correlation pattern between K and N, suggesting some cross-correlation involving these two elements at the leaf level, which allows the creation of vegetation indices close to these regions. In addition, other studies report the importance of wavelengths of the green $^{68}$ and red ${ }^{69}$ regions to estimate the concentration of $\mathrm{P}$ and $\mathrm{K}$ in plants.

The important wavelengths selected for Ca prediction were found in two regions (around 550 and $720 \mathrm{~nm}$ ), according to previous research studies such as Oliveira and Santana ${ }^{66}$ studying the $\mathrm{Ca}$ content in Eucalyptus. The reflectance in wavelengths near from $500 \mathrm{~nm}$ is associated with active photosynthetic radiation, ${ }^{49}$ especially the role of $\mathrm{Ca}$ as a cofactor in the photosystem II. ${ }^{70}$ The NIR region also presented higher absolute RC values for Ca prediction. Among the functions of $\mathrm{Ca}$ in higher plants are cell wall synthesis and cell membrane integrity. ${ }^{71}$ In this sense, there is a relationship between the structural components (mesophyll) and the energy in the NIR region. ${ }^{42}$

For $\mathrm{Mg}$, the largest RC near $680 \mathrm{~nm}$ can be related to the chlorophyll molecule since $\mathrm{Mg}$ integrates it, besides being an activator of some enzymes in plants. ${ }^{71}$ Regarding $\mathrm{S}$, the high values of RC at near $700 \mathrm{~nm}$ are supported by the work by Cozzolino and Moron, ${ }^{54}$ who found, near this region, high correlations with S. Furthermore, wavelengths in this region have been used in the management of $\mathrm{S}$ in wheat (Triticum aestivum L.). ${ }^{72}$ Finally, for $\mathrm{Zn}$, the high values of RC around 400 and $620 \mathrm{~nm}$ can be related to chlorophyll, ${ }^{41}$ which, in turn, can be correlated with nutrient concentrations. ${ }^{64}$

\subsection{Applications of Vis-NIR Spectroscopy as a Technique for Estimating LDM and Nutrients Contents in Soybean}

Soybean plants require significant amounts of mineral nutrients to achieve adequate growth and productivity, and this need depends on the fertility and class of the soil. Although the mineral nutrition of soybeans and the conventional techniques for assessing the nutritional status are much studied, there is limited research on the use of alternative techniques to routine analysis, such as the use of the Vis-NIR spectroscopy in predicting LDM and leaf nutrient contents.

Soybean leaves are a complex mixture of chemical compounds such as water, pigments, carbohydrates, proteins, and others. All these compounds contribute substantially to generate a characteristic spectrum of the target (leaves). The nutritional and physical state of the plant (thickness and roughness) also helps to form a differentiated spectrum. In this study, the application of mining coproducts (alternative inputs) in the soil, different in input particle size and solubility, allowed a wide diversity of nutritional conditions, varying between better-nourished plants and others with deficiencies (Table 4). Thus, there was a high CV for the evaluated variables, which affected, in part, the creation of models with better $R_{p}^{2}$ and $\mathrm{RPD}_{\mathrm{p}}$ for certain variables. $^{73}$

Despite its limiting conditions, this study demonstrates potential use of the Vis-NIR spectroscopy to predict variables that presented $R^{2}$ and $\mathrm{RPD}_{\mathrm{p}}$ above 0.50 and 1.50 , respectively, as it 
was the case of variables LDM, $\mathrm{P}, \mathrm{K}, \mathrm{Mg}, \mathrm{S}$, and $\mathrm{Zn}$, with emphasis on the first four, which presented $R_{\mathrm{p}}^{2}$ above 0.65 .

The results of this study demonstrated that a system based on a portable equipment, such as the Vis-NIR spectrometer, can provide a better knowledge of the nutritional condition of certain nutrients as well as estimate LDM of soybean grown after application of mining coproducts. Because it is a fast, low-cost, and non-destructive method, Vis-NIR spectroscopy can be applied in areas cultivated with annual crops such as soybean. Due to the ease of acquisition of this equipment and the processing of the data, it can be used in areas with precision agriculture, considering that this type of agriculture requires a large number of samples. ${ }^{74}$ Although there are many studies reporting the use of the Vis-NIR-SWIR range as a technique for predicting nutrients in plants, this work demonstrated that the use of the Vis-NIR (380 to $1000 \mathrm{~nm}$ ) range has the potential to generate satisfactory prediction models for several attributes of soybean plants. This allows for the acquisition of cheaper spectroradiometers, which do not necessarily need to operate in the SWIR range.

Finally, the positive results obtained, in this study, indicate that it may also be feasible to use of the Vis-NIR spectroscopy to evaluate other chemical compounds present in soybean that are important in commercialization.

\section{Conclusion}

The application of mining coproducts enabled a wide diversity of nutritional conditions in soybean cultivation, what modified the spectral curves of the plants and contributed to the high range of minimum and maximum values of the nutrient contents (plants).

With the use of PLSR, it was possible to adjust models in the prediction stage with $R_{\mathrm{p}}^{2}$ and $\mathrm{RPD}_{\mathrm{p}}$ above 0.50 and 1.50 , respectively, for $\mathrm{LDM}, \mathrm{P}, \mathrm{K}, \mathrm{Mg}, \mathrm{S}$, and $\mathrm{Zn}$.

The contents of $\mathrm{N}, \mathrm{Ca}, \mathrm{Cu}, \mathrm{Fe}$, and $\mathrm{Mn}$ showed models with imprecise adjustments $\left(R_{\mathrm{p}}^{2}<0.50\right)$, compromising the good prediction of these plant nutrients.

In general, the most important wavelengths for the construction of the PLSR model according to the regression coefficients were close to 380 to $400 \mathrm{~nm}, 500$ to $530 \mathrm{~nm}, 600$ to $690 \mathrm{~nm}$, and 700 to $750 \mathrm{~nm}$.

The study confirms the potential of using Vis-NIR spectroscopy to predict LDM and nutrients contents in soybean crops. Thus, Vis-NIR spectroscopy presents itself as a promising alternative to the routine analysis of the nutritional diagnosis of plants for having advantages such as speed, low cost, and no use of reagents that are toxic to the environment; due to the ease of data acquisition and processing, the Vis-NIR spectroscopy allows application in areas with precision agriculture. Further research is necessary to develop more robust models for nutrients such as $\mathrm{N}, \mathrm{Ca}, \mathrm{Cu}, \mathrm{Fe}$, and $\mathrm{Mn}$ with control of the variation of individual nutrients.

Although there are studies reporting the use of spectroscopy as a technique for predicting nutrients in plants, the Vis-NIR-SWIR range is used in most studies. Thus, the results found in the present work are promising since only the Vis-NIR range was used and it was possible to build models with good prediction for different nutrients. This allows for the acquisition of cheaper spectroradiometers, which do not necessarily need to operate in the SWIR range.

\section{Acknowledgments}

The authors would like to thank the Coordenação de Aperfeiçoamento de Pessoal de Nível Superior (CAPES) for the financial support and the State University of Maringá for the use of their infrastructure and logistics. The authors declare no conflicts of interest in this study. This study was funded by Coordenação de Aperfeiçoamento de Pessoal de Nível Superior (Grant No. 88882.344504/2019-01).

\section{References}

1. A. J. Cattelan and A. Dall'Agnol, "The rapid soybean growth in Brazil," OCL 25(1), D102 (2018). 
2. Conab, Acompanhamento da Safra Brasileira de Grãos, 7th ed., Conab, Brasília (2019).

3. P. Van Straaten, "Farming with rocks and minerals: challenges and opportunities," An. Acad. Bras. Cienc. 78(4), 731-747 (2006).

4. A. Sharpley, "Managing agricultural phosphorus to minimize water quality impacts," Sci. Agric. 73(1), 1-8 (2016).

5. R. F. Muñoz-Huerta et al., "A review of methods for sensing the nitrogen status in plants: advantages, disadvantages and recent advances," Sensors 13(8), 10823-10843 (2013).

6. P. Pandey et al., "High throughput in vivo analysis of plant leaf chemical properties using hyperspectral imaging," Front. Plant Sci. 8, 1348 (2017).

7. H. Kobori et al., "Applicability of Vis-NIR hyperspectral imaging for monitoring wood moisture content (MC)," Holzforschung 67(3), 307-314 (2013).

8. A. Radzevičius et al., "Determination of tomato quality attributes using near infrared spectroscopy and reference analysis," Zemdirbyste-Agric. 103(1), 443-448 (2016).

9. G. A. Blackburn, "Hyperspectral remote sensing of plant pigments," J. Exp. Bot. 58(4), 855-867 (2007).

10. X. Tang et al., "Comparison of methods for estimating soybean chlorophyll content based on visual/near infrared reflection spectra," Spectrosc. Spectr. Anal. 31(2), 371-374 (2011).

11. Y. Ge et al., "High-throughput analysis of leaf physiological and chemical traits with VISNIR-SWIR spectroscopy: a case study with a maize diversity panel," Plant Methods 15(1), 66 (2019).

12. C. R. Yendrek et al., "High-throughput phenotyping of maize leaf physiological and biochemical traits using hyperspectral reflectance," Plant Physiol. 173(1), 614-626 (2017).

13. P. Menesatti et al., "Estimation of plant nutritional status by Vis-NIR spectrophotometric analysis on orange leaves [Citrus sinensis (L) Osbeck cv Tarocco]," Biosyst. Eng. 105(4), 448-454 (2010).

14. L. Galvez-Sola et al., "Rapid estimation of nutritional elements on citrus leaves by near infrared reflectance spectroscopy," Front. Plant Sci. 6, 571 (2015).

15. C. J. Yarce and G. Rojas, "Near infrared spectroscopy for the analysis of macro and micro nutrients in sugarcane leaves," Zuckerindustrie-Sugar Ind. 137(11), 707 (2012).

16. S. Wold et al., "Some recent developments in PLS modeling," Chemom. Intell. Lab. Syst. 58(2), 131-150 (2001).

17. E. L. da Fonseca, J. R. F. Caresani, and A. C. Varella, "Caracterização espectral multitemporal dos cereais de estação fria em imagens de satélite com média resolução espacial," Ciência Rural 40(10), 2053-2059 (2010).

18. R. Vijayaragavan et al., "Physico-mechanical investigations on mineralogical clay-based ceramic bodies with rock residue," J. King Saud Univ. Eng. Sci. 30(2), 188-194 (2018).

19. D. K. Smith and R. Jenkins, "The powder diffraction file: past, present, and future," J. Res. Natl. Inst. Stand. Technol. 101(3), 259 (1996).

20. WRB, "World reference base for soil resources 2014: international soil classification system for naming soils and creating legends for soil maps," World Soil Resources Reports 106, p. 192 (2015).

21. P. C. Teixeira et al., Manual de Métodos de Análise de Solo, Embrapa, Rio Janeiro (2017).

22. G. H. Korndörfer, Silicatos de Cálcio e Magnésio na Agricultura, 1st ed., GPSi-ICIAGUFU, Uberlândia (2002).

23. H. E. Shoemaker, E. O. McLean, and P. F. Pratt, "Buffer methods for determining lime requirement of soils with appreciable amounts of extractable aluminum," Soil Sci. Soc. Am. J. 25(4), 274-277 (1961).

24. CQFS-RS/SC, Manual de Calagem e Adubação Para os Estados de Rio Grande do Sul e de Santa Catarina, 3rd ed., SBCS, Santa Maria (2016).

25. F. C. Da Silva, Manual de Análises Químicas de Solos, Plantas e Fertilizantes, Embrapa Informação Tecnológica, Rio de Janeiro (2009).

26. LABSPHERE, Reflectance Calibration Laboratory, Sutton (1996).

27. M. R. Nanni and J. A. M. Demattê, "Spectral reflectance methodology in comparison to traditional soil analysis," Soil Sci. Soc. Am. J. 70(2), 393-407 (2006).

28. S. Addinsoft, XLSTAT Software, Version 9.0, Addinsoft, Paris (2010). 
29. Q. Li, Q. Gao, and G. Zhang, "Improved extended multiplicative scatter correction algorithm applied in blood glucose noninvasive measurement with FT-IR spectroscopy," J. Spectrosc. 2013, 916351 (2013).

30. M. Rodrigues et al., "Evaluation of the use of spectroradiometry for the determination of soil exchangeable ions after the application of mining coproducts," Appl. Spectrosc. Rev. 55(6), 491-508 (2020).

31. H. Martens and T. Naes, Multivariate Calibration, John Wiley \& Sons (1992).

32. Y. Zhai et al., "Estimation of nitrogen, phosphorus, and potassium contents in the leaves of different plants using laboratory-based visible and near-infrared reflectance spectroscopy: comparison of partial least-square regression and support vector machine regression met," Int. J. Remote Sens. 34(7), 2502-2518 (2013).

33. M. R. Nanni et al., "Partial least squares regression (PLSR) associated with spectral response to predict soil attributes in transitional lithologies," Arch. Agron. Soil Sci. 64(5), 682-695 (2018).

34. R. A. V. Rossel et al., "Visible, near infrared, mid infrared or combined diffuse reflectance spectroscopy for simultaneous assessment of various soil properties," Geoderma 131(1-2), 59-75 (2006).

35. W. Saeys, A. M. Mouazen, and H. Ramon, "Potential for onsite and online analysis of pig manure using visible and near infrared reflectance spectroscopy," Biosyst. Eng. 91(4), 393-402 (2005).

36. C.-W. Chang et al., "Near-infrared reflectance spectroscopy-principal components regression analyses of soil properties," Soil Sci. Soc. Am. J. 65(2), 480-490 (2001).

37. B. W. Dunn et al., "The potential of near-infrared reflectance spectroscopy for soil analysis-a case study from the Riverine Plain of south-eastern Australia," Aust. J. Exp. Agric. 42(5), 607-614 (2002).

38. K. Goldberg and M. Humayun, "Geochemical paleoredox indicators in organic-rich shales of the Irati Formation, Permian of the Paraná Basin, southern Brazil," Brazilian J. Geol. 46(3), 377-393 (2016).

39. A. Zanardo et al., "Formação Corumbataí na região de Rio Claro/SP: petrografia e implicações genéticas," Geociências 35(3), 322-345 (2016).

40. S. R. Christofoletti and M. M. T. Moreno, "Comparação tecnológica, mineralógica e química da Formação Corumbataí em dois polos cerâmicos distintos visando sua aplicação na indústria de revestimentos cerâmicos," Cerâmica 61(360), 469-476 (2015).

41. S. L. Ustin et al., "Retrieval of foliar information about plant pigment systems from high resolution spectroscopy," Remote Sens. Environ. 113, S67-S77 (2009).

42. J. Liu et al., "Nondestructive detection of rape leaf chlorophyll level based on Vis-NIR spectroscopy," Spectrochim. Acta Part A 222, 117202 (2019).

43. F. Pimentel-Gomes, Statistics Course Experimental, FEALQ, Piracicaba (2009).

44. M. Gutierrez et al., "Association of spectral reflectance indices with plant growth and lint yield in upland cotton," Crop Sci. 52(2), 849-857 (2012).

45. Y. Li et al., "Factors influencing leaf chlorophyll content in natural forests at the biome scale," Front. Ecol. Evol. 6, 64 (2018).

46. L. A. Ivanova, "Restructuring of the leaf mesophyll in a series of plant life forms," Dokl. Biol. Sci. 447(1), 386 (2012).

47. L. K. Christensen et al., "Modelling nitrogen and phosphorus content at early growth stages in spring barley using hyperspectral line scanning," Biosyst. Eng. 88(1), 19-24 (2004).

48. X. J. Zhang and M. Z. Li, "Analysis and estimation of the phosphorus content in cucumber leaf in greenhouse by spectroscopy," Spectrosc. Spect. Anal. 28(10), 2404-2408 (2008).

49. X. Zhang et al., "Detecting macronutrients content and distribution in oilseed rape leaves based on hyperspectral imaging," Biosyst. Eng. 115(1), 56-65 (2013).

50. V. Silva-Perez et al., "Hyperspectral reflectance as a tool to measure biochemical and physiological traits in wheat," J. Exp. Bot. 69(3), 483-496 (2018).

51. A. Pimstein et al., "Exploring remotely sensed technologies for monitoring wheat potassium and phosphorus using field spectroscopy," F. Crop. Res. 121(1), 125-135 (2011). 
52. J. G. Ferwerda and A. K. Skidmore, "Can nutrient status of four woody plant species be predicted using field spectrometry?" ISPRS J. Photogramm. Remote Sens. 62(6), 406-414 (2007).

53. E. Cezar et al., "Organic matter and sand estimates by spectroradiometry: strategies for the development of models with applicability at a local scale," Geoderma 340, 224-233 (2019).

54. D. Cozzolino and A. Moron, "Exploring the use of near infrared reflectance spectroscopy (NIRS) to predict trace minerals in legumes," Anim. Feed Sci. Technol. 111(1-4), 161-173 (2004).

55. D. H. Clark, H. F. Mayland, and R. C. Lamb, "Mineral analysis of forages with near infrared reflectance spectroscopy," Agron. J. 79(3), 485-490 (1987).

56. D. A. Burns and E. W. Ciurczak, Handbook of Near-Infrared Analysis, 1st ed., CRC Press (2007).

57. M. Garriga et al., "Use of Vis-NIR reflectance data and regression models to estimate physiological and productivity traits in lucerne (Medicago sativa)," Crop Pasture Sci. 71(1), 90-100 (2020).

58. V. A. Tzanakakis, A. Mauromoustakos, and A. N. Angelakis, "Prediction of biomass production and nutrient uptake in land application using partial least squares regression analysis," Water 7(1), 1-11 (2015).

59. M. van Maarschalkerweerd, "New ways to determine plant nutrient deficiences using fast spectroscopy," Department of Plant and Environmental Sciences, Faculty of Science (2014).

60. V. D. Fageria, "Nutrient interactions in crop plants," J. Plant Nutr. 24(8), 1269-1290 (2001).

61. C. Huang et al., "Exploring the use of near infrared reflectance spectroscopy to predict minerals in straw," Fuel 88(1), 163-168 (2009).

62. H. Liao et al., "Rapid diagnosis of nutrient elements in fingered citron leaf using near infrared reflectance spectroscopy," J. Plant Nutr. 35(11), 1725-1734 (2012).

63. M. K. D. Rambo et al., "Prediction by multivariate calibration of quality parameters of coffee residues," Ciência e Nat. 37(2), 374-380 (2015).

64. B. R. Stein et al., "Predicting macronutrient concentrations from loblolly pine leaf reflectance across local and regional scales," GIScience Remote Sens. 51(3), 269-287 (2014).

65. K.-Q. Yu et al., "Hyperspectral imaging for mapping of total nitrogen spatial distribution in pepper plant," PLoS One 9(12), e116205 (2014).

66. L. F. R. de Oliveira and R. C. Santana, "Estimation of leaf nutrient concentration from hyperspectral reflectance in Eucalyptus using partial least squares regression," Sci. Agric. 77(6) (2020).

67. B. Dechant et al., "Estimation of photosynthesis traits from leaf reflectance spectra: correlation to nitrogen content as the dominant mechanism," Remote Sens. Environ. 196, 279-292 (2017).

68. N. M. Milton, B. A. Eiswerth, and C. M. Ager, "Effect of phosphorus deficiency on spectral reflectance and morphology of soybean plants," Remote Sens. Environ. 36(2), 121-127 (1991).

69. K. Kawamura et al., "Potential for spectral indices to remotely sense phosphorus and potassium content of legume-based pasture as a means of assessing soil phosphorus and potassium fertility status," Int. J. Remote Sens. 32(1), 103-124 (2011).

70. P. E. M. Siegbahn and R. H. Crabtree, "Manganese oxyl radical intermediates and O-O bond formation in photosynthetic oxygen evolution and a proposed role for the calcium cofactor in photosystem II," J. Am. Chem. Soc. 121(1), 117-127 (1999).

71. H. Marschner, Marschner's Mineral Nutrition of Higher Plants, Academic Press (2011).

72. G. R. Mahajan et al., "Using hyperspectral remote sensing techniques to monitor nitrogen, phosphorus, sulphur and potassium in wheat (Triticum aestivum L.)," Precis. Agric. 15(5), 499-522 (2014).

73. M. K. D. Rambo et al., "Prediction of quality parameters of food residues using NIR spectroscopy and PLS models based on proximate analysis," Food Sci. Technol. 40(2), 444-450 (2020).

74. V. Alchanatis, Z. Schmilovitch, and M. Meron, "In-field assessment of single leaf nitrogen status by spectral reflectance measurements," Precis. Agric. 6(1), 25-39 (2005). 
Marlon Rodrigues received his MSc degree in science from the Federal University of Pelotas, Brazil, in 2017. He is currently a PhD student at State University of Maringá, Brazil. His research interests include surveying and mapping, nutrients, and plant biomass estimation using remote sensing.

Marcos Rafael Nanni is a full professor at the State University of Maringá, Brazil. His research interests include remote sensing, geoprocessing, geographic information system, soil survey and cartography, diagnosis and planning of conservation units, diagnosis and agricultural planning, and precision agriculture. He has authored more than 200 publications, including more than 100 journal papers. He is currently the coordinator of the Graduate Program in Agronomy (concept 6) at UEM.

Everson Cezar is currently an adjunct professor in the Department of Agronomy, the State University of Maringá, where he teaches the discipline of soil and fertilization, soil fertility, soil classification and geoinformation applied to agronomy, soil genesis, and morphology and precision agriculture. He has authored more than 100 publications, including more than 40 journal papers.

Glaucio Leboso Alemparte Abrantes dos Santos received his MSc degree in agronomy from the Federal University of Viçosa, Brazil, in 2011. He is currently a PhD student at the State University of Maringá, Brazil, and a professor at the Centro Universitário Ingá, Brazil. His research interests include surveying and mapping, soil attributes estimation using remote sensing.

Amanda Silveira Reis received her MSc degree in agronomy from the State University of Northern Paraná, Brazil, in 2017. She is currently a PhD student at State University of Maringá, Brazil. Her research interests include surveying and mapping, soil organic matter estimation using remote sensing.

Karym Mayara de Oliveira received her MSc degree in agronomy from the State University of Maringá, Brazil, in 2020. She is currently a PhD student at State University of Maringá, Brazil. Her research interests include biomass and plant nutrients prediction using remote sensing applications.

Roney Berti de Oliveira is currently an adjunct professor in the Department of Civil Engineering, the State University of Maringá, where he teaches the discipline of geoprocessing applied to soil survey and spatialization and topography applied to architecture and urbanism. He has authored more than 90 publications, including more than 20 journal papers. 